\title{
Protecting Indigenous Peoples through Right to Natural Resources: Lesson from the Existence of Navajo Tribe in the United States
}

\author{
I Gusti Ngurah Parikesit Widiatedja \\ Faculty of Law, Udayana University \\ Jln. Pulau Bali No.1, Denpasar, 80225, Bali \\ Tel./Fax.+62-361-223797E-mail: ngurahparikesit@gmail.com
}

Submitted: Oct 19, 2015; Reviewed: Nov 21, 2015; Accepted: Nov 27, 2015

\begin{abstract}
From the perspective of international law, indigenous peoples have the rights to own, use, and control their natural resources within their territories. In the United States, the Navajo Tribe has enjoyed those rights. In terms of law making process, this tribe can enact some acts to preserve a control over their natural resources. Specifically, the Air Pollution Prevention and Control Act, the Clean Water Act, and the Solid Waste Act. Concerning law implementation and enforcement, Navajo Tribe has a right to equitable benefit sharing in natural resources and fair court proceeding for breach. As a result, the existence of rights for natural resources requires the U.S federal government to ensure fair administration of natural resources in order to mitigate an economic exploitation of natural resources in indigenous land.
\end{abstract}

Keywords: Indigenous Peoples; Navajo Tribe; Right to Natural Resources

\section{INTRODUCTION}

It is generally regulated that indigenous peoples have the rights for possessing, using, and controlling their natural resources within their regions. ${ }^{1}$ Though this recognition has been widely accepted under myriad international treaties, it remains doubtful in many countries that has resulted in excruciating injury for indigenous peoples. Specifically,

\footnotetext{
S. James Anaya. (2009). International Human Rights and Indigenous Peoples. Aspen Publ/ Wolters Kluwer Law and Business, pg.1
} 
Tracing this irony, there are several drawbacks including: low level of investment, improper policies, massive land acquisitions, unfair competition, corruption and mismanagement. ${ }^{4}$ Equally important, the indigenous peoples themselves did not realize if they have power to govern and to administer their natural resources in their areas. ${ }^{5}$ As a consequence, government and greedy investors take an advantage from this reality by exploiting all natural resource inside indigenous land without giving proper participation, and fair as well as equitable benefit sharing. ${ }^{6}$

In the United States' patterns, each Native American tribes, including the Navajo, has considerable positions concerning exploitation, administration, and distribution of the natural resources that are originate on indigenous lands. ${ }^{7}$ Specifically, they can establish some policies or technical tools to preserve control over their natural resources. ${ }^{8}$ Furthermore, tribes can also create applicable procedures for the objective of ensuring adequate standards of environmental quality for the Indigenous peoples. ${ }^{9}$ On the

4 Ibid.

5 Eric Lemont. (2002). "Developing Effective Process of American Indian Constitutional and Governmental Reform: Lessons from the Cherokee Nation of Oklahoma, Hualapai Nation, Navajo Nation, and Northern Cheyenne Tribe". American Indian Law Review, Vol. 26, pg.155

6 Jide James-Eluyod, (2012). "Collective Rights to Lands and Resources: Exploring the Comparative Natural Resource Revenue Allocation Model of Native American Tribes and Indigenous African Tribes". Arizona Journal of International and Comparative Law, Vol. 29, pg.177.

Eluyod, Op.Cit, pg. 181

8 Mark Allen. (1989). "Native American Control of Tribal Natural Resource Development in the Context of the Federal Trust and Tribal Self-Determination". Boston College Environmental Affairs Law Review, Vol.16, pg. 857

9 S. James Anaya \& Robert A. Williams, Jr. (2001). "The Protection of Indigenous Peoples' Rights over Lands and Natural Resources Under the Inter- other hand, federal government posits as a trustee on behalf of the tribes. ${ }^{10}$ Sooner or later, this responsibility stipulates the federal government to warrant fair and just administration of natural resources based on the need and the interest of indigenous groups. ${ }^{11}$

This paper will explain the practice of the U.S federal government in granting right to natural resources for Navajo Tribe as a means of protection for indigenous peoples in the globalized world. To begin with, this paper will identify international law that recognize right to natural resources for indigenous peoples. Next, it will provide brief description of the existence of Navajo Tribe in the U.S. Then, it will reveal the way of the U.S federal government to protect the existence of indigenous peoples in the globalized world by providing rights to natural resources.

\section{ANALYSIS AND DISCUSSION}

Right to Natural Resources under International Law

Under International Law, the right of natural resources is derived from the article I (2) International Covenant on Civil and Political Rights (ICCPR) and International Covenant on Economic, Social and Cultural Rights (ICESCR). Those covenants have admitted the right of all peoples including indigenous peoples to independently organize their natural resources. Next, they must not be dis-

American Human Rights System". Harvard Human Rights Journal, Vo.14, pg. 33

10 Janice Aitken. (1997). "The Trust Doctrine in Federal Indian Law: A Look at Its Development and at How Its Analysis Under Social Contract Theory Might Expand Its Scope". Northern Illinois University Law Review, Vol.18, pg.115

11 Kevin Gover. (2006). "An Indian Trust for the Twenty-First Century". Natural Resources Journal, Vol.46 (2006), pg. 340 
possessed because of the cooperation in economic among member states. ${ }^{12}$

The International Labor Organization Convention No. $169^{13}$ and the United Nations Declaration on the Rights of Indigenous Peoples (UNDRIP) of $2007^{14}$ have expressly recognized the integral rights of indigenous peoples covering rights of people to their inherited lands, territories, natural resources, and to execute control and administration over their lands and resources. ${ }^{15}$ Specifically, article 15.1 ILO Convention 1969 required that the states must protect the rights of indigenous peoples to independently utilize, manage, and conserve their resources. ${ }^{16}$ Subsequently, article 15.2 required that indigenous peoples must be granted by the rights to be consulted, participated related to profit from the exploitation of their resources. Equally important, states

12 See generally Article I(2) International Covenant on Civil and Political Rights, G.A. Res. 2200 (XXI) A, U.N.Doc.A/RES/220(XXI) (Dec. 16, 1966); International Covenant on Economic, Social and Cultural Rights, G.A. Res. 2200 (XXI) A, U.N.Doc.A/ RES/220(XXI) (Dec. 16, 1966) that stated: "All peoples may, for their own ends, freely dispose of their natural wealth and resources without prejudice to any obligations arising out of international economic co-operation, based upon the principle of mutual benefit, and international law. In no case may a people be deprived of its own means of subsistence."

13 International Labour Organisation, Indigenous and Tribal Peoples Convention, 1989 (No. 169), June 27, 1989, [hereinafter ILO Convention No. 169].

14 Declaration on the Rights of Indigenous Peoples, G.A. Res. 61/295, U.N. Doc. A/RES/61/295 (Sept. 13, 2007) [hereinafter UNDRIP].

15 See U.N. DEP'T OF ECON. \& SOC. AFFAIRS, STATE OF THE WORLD'S INDIGENOUS PEOPLES, p. 86, U.N. Doc. ST/ESA/328, U.N. Sales No. 09.VI.13 (2009).

16 Article 15.1 ILO Convention No.169 stated that: The rights of the peoples concerned to the natural resources pertaining to their lands shall be special safeguarded. These rights include the right of these peoples to participate in the use, management and conservation of these resources. should provide adequate compensation such exploitation has emerged some injuries for indigenous peoples. ${ }^{17}$

In more specific law, Declaration on the Rights of Indigenous Peoples (UNDRIP) have comprehensively regulated the right of natural resources for indigenous peoples. Article 26 stated that the lands and territories that based on customary law and practice populated and inhabited by indigenous peoples, they have rights to build, organize and utilize that land and resources. Then, states must ensure the protection from those lands and resources considering the existing customary law and practice from indigenous peoples. $^{18}$

Next, Article 32 stipulated the right of indigenous peoples to choose and build methods and ways for developing and using their resources. Then, in order to prevent the detrimental effect of exploitation, state must work together with indigenous peoples, and

17 Article 15.2 ILO Convention 169 stated that: In cases in which the State retains the ownership of mineral or sub-surface resources or rights to other resources pertaining to lands, governments shall establish or maintain procedures through which they shall consult these peoples, with a view to ascertaining whether and to what degree their interests would be prejudiced, before undertaking or permitting any programmes for the exploration or exploitation of such resources pertaining to their lands. The peoples concerned shall wherever possible participate in the benefits of such activities, and shall receive fair compensation for any damages which they may sustain as a result of such activities.

18 Article 26 UNDRIP stated that: (1) Indigenous peoples have the right to the lands, territories and resources which they have traditionally owned, occupied or otherwise used or acquired; (2) Indigenous peoples have the right to own, use, develop and control the lands, territories and resources that they possess by reason of traditional ownership or other traditional occupation or use, as well as those which they have otherwise acquired; (3) States shall give legal recognition and protection to these lands, territories and resources. Such recognition shall be conducted with due respect to the customs, traditions and land tenure systems of the indigenous peoples concerned. 
states must get an formal agreement before developing or utilizing indigenous' resources. Equally important, states should offer just and appropriate mechanism to mitigate the multilayers negative impact of the development of resources within indigenous land. ${ }^{19}$

Furthermore, the United Nations Declaration on The Right to Development through Resolution No.A/RES/41/1284 December 1986 also stated through Article 1 that every peoples must have right to actively involve and gain benefit from the development of social, politics, and economy as well as culture. Specifically, they have complete sovereignty for their natural resources. Article 2, then, stipulated the obligation of state to arrange fair national development program for peoples who are actively participate to the development of their resources. States also obliged to provide fair mechanism to share benefit from the exploitation of such resources. ${ }^{20}$

19 Article 32 UNDRIP stated that: (1) Indigenous peoples have the right to determine and develop priorities and strategies for the development or use of their lands or territories and other resources; (2) States shall consult and cooperate in good faith with the indigenous peoples concerned through their own representative institutions in order to obtain their free and informed consent prior to the approval of any project affecting their lands or territories and other resources, particularly in connection with the development, utilization or exploitation of mineral, water or other resources; (3) States shall provide effective mechanisms for just and fair redress for any such activities, and appropriate measures shall be taken to mitigate adverse environmental, economic, social, cultural or spiritual impact.

20 The United Nations Declaration on The Right to Development through Resolution No.A/RES/ 41/128, 4 December 1986 completely stated that: Article 1: (1) The right to development is an inalienable human right by virtue of which every human person and all peoples are entitled to participate in, contribute to, and enjoy economic, social, cultural and political development, in which all human rights and fundamental freedoms can be fully realized; (2) The human right to development also implies the full realization of the right of peoples to self-determination, which includes, subject to the
The Existence of Navajo Tribe in the United States

According to the United States' constitutional pattern, tribes are the third sovereign beside the state and federal government sovereigns. ${ }^{21}$ At this time, approximately 500 tribes are progressively executing their power for administering in executive, legislative, and judicial activities that give effect to subject matter important to members and to non-members. ${ }^{22}$ Equally important, tribes are not stipulated to obey with the Constitution of the United States while building their tribal governments or rules because they are classified as an extra-constitutional. ${ }^{23}$

For instance, following the Treaty of 1866 that involved the Unites States federal government and the Cherokee Nation, the U.S. Supreme Court, in Cherokee Nation v. Journeycake, held that the lands and territories subject to the treaty were the collective property of all Cherokee citizens, and that the tribe embraces complete common rights and property interests in the particular territory. ${ }^{24}$ Hence, separate from the federal and state governmental pattern, tribal government produces a fundamental and legally

relevant provisions of both International Covenants on Human Rights, the exercise of their inalienable right to full sovereignty over all their natural wealth and resources.

Article 2: (3) States have the right and the duty to formulate appropriate national development policies that aim at the constant improvement of the well-being of the entire population and of all individuals, on the basis of their active, free and meaningful participation in development and in the fair distribution of the benefits resulting therefrom.

${ }^{21}$ Gloria Valencia-Weber. (1994). "Tribal Courts: Custom and Innovative Law". New Mexico Law Review, Vol.24, pg. 225.

22 Ibid.

23 United States Court of Appeals for the Tenth Circuit in Santa Clara Pueblo v. Martinez, 436 U.S. 49, 6263 (1978)

24 See, United States Supreme Court in Cherokee Nation v. Journeycake, 155 U.S. 196 (1894). 
acknowledged layer of government. ${ }^{25}$ This situation generated the linking between tribal and the federal government as a "government to government" linking. ${ }^{26}$ In order to execute this power, most tribes in the United States have enacted formal constitutions and other regulatory procedure that allow them to execute jurisdiction cover miscellaneous activities within their territories, including taxation, civil action, and crime. ${ }^{27}$

One of the most prominent tribe in the United States is the Navajo Tribe that are presumed to be the largest tribe of all $\mathrm{Na}$ tive American Indians. ${ }^{28}$ They inhabited over 27,000 square miles, covering three states, namely, the northwestern side of New Mexico, the southeastern side of Utah, and northeastern side of Arizona. ${ }^{29}$ Historically, the Navajo was established as a sovereign area by the Navajo Treaty of 1868 between the tribe and the United States (federal government). ${ }^{30}$ Navajo Tribe had an independent method of government for a long time, but the unearthing of oil and other natural resources on the Navajo are in the early the twentieth century obliged the formation of a more designed and viable types of tribal government. ${ }^{31}$

In 1923, an organization of formal governmental was admitted by the United States in order to deal with the fast increasing voyages of business entities, including oil

25 Eluyod, Op.Cit, pg. 183

$26 \quad$ Ibid. pg. 184

7 Ibid.pg. 190

28 Navajo People - The Dine, http://navajopeople.org/ (last visited Sept.18, 2014).

29 Ibid.

30 Raymond Darrel Austin. (2009). Navajo Courts and Navajo Common Law: a Tradition of Tribal Self Governance, Minneapolis: University of Minnesota Press, pg. 6.

$31 \quad$ Ibid. pg.39 and mining corporations. ${ }^{32}$ Recently, natural resources such as coal generate millions of dollars in income for the tribe. ${ }^{33}$

\section{Right to Natural Resources for Navajo Tribe}

This section will explain how Navajo Tribe has an authority to govern its own affairs within its own territorial, especially to reflect right to natural resources. There are two parameters how they can exercise right to natural resources including the following: (1) how they can establish some acts or regulatory instruments to preserve control over their natural resources; and (2) how they have rights to equitable benefit sharing in natural resources and accountability for breach.

\section{The Establishment of Tribal Acts}

In terms of establishment of acts, Navajo Tribe has enacted several environmental acts, including the Air Pollution Prevention and Control Act, the Clean Water Act, and the Solid Waste Act. ${ }^{34}$

Navajo Nation Air Pollution Prevention and Control Act ${ }^{35}$

Due to the potential of the abstraction of natural resource that cause air pollutions, Navajo tribe has enacted the Navajo Na-

32 Navajo Tourism Dep't, The History of Cowboys and Indians, Discover Navajo, http:// discovernavajo. com/Cowboys \%20\&\%20Indians-1.pdf. (Last visited Sept. 16, 2014)

33 Ibid.

34 S. Solomon et al. Intergovernmental Panel on Climate Change, Summary for Policymakers, in Climate Change 2007: The Physical Science Basis, available at http://www.ipcc.ch/pdf/assessmentreport/ar4/wg1/ar4-wg1-spm.pdf.

35 Navajo Nation Air Pollution Prevention and Control Act, Navajo Nation Code Ann. tit. 4, § 1101-1162 (2010); St. Regis Mohawk Tribe, Tribal Implementation Plan (2004), available at http:// www.srmtenv.org/pdf_files/airtip.pdf; 
tion's Air Pollution Prevention and Control Act ("NN APPCA"). The goal of this act is to control future sources of air pollution on the Navajo Nation. Specifically, this act provides for the regulation of air pollution activities in a way that ensures the health, safety and general welfare of all the populations of the Navajo, protects property values, and protects plant and animal life. ${ }^{36}$

Equally important, the NN APPCA stipulates regular reports of air quality that are useful in defining where air pollution is (or will be) predominantly dominant within the Navajo's territory. For instance, Navajo agencies demanding to "carry out or approve a Navajo-funded project linking to transportation that may have substantial impact on air quality must complete and file with the Nation an air quality report.

Moreover, the NN APPCA also includes enforcement provisions. When the Navajo Nation's Executive Director of the Navajo Nation Environmental Protection Agency ("Director") concludes that the NN APPCA has been violated or is being violated, the Director may: 1) issue an order to comply; ${ }^{37} 2$ ) issue an administrative penalty; ${ }^{38} 3$ ) bring a civil action, ${ }^{39}$ and 4 ) pursue a criminal action. ${ }^{40}$

\section{Navajo Nation Clean Water Act ${ }^{41}$}

Because of the close connection between natural resource development, especially for energy purposes,-and water usage,

\footnotetext{
36 Navajo Nation Air Pollution Prevention and Control Act, Navajo Nation Code Ann. tit. 4, § 1101-1162 (2010).

37 Ibid. $\$ 1152(\mathrm{C})$

8 Ibid. $\S 1155(\mathrm{~A})$

Ibid. $\S 1154(\mathrm{~A})$.

$40 \quad$ Ibid. § 1154(B).

41 Navajo Nation Water Code, tit. 22, ch. 7, §§ 1011405 (1984).
}

Navajo Tribe has enacted its own Clean Water Act ("NN CWA"). ${ }^{42}$ The Navajo Nation Council declares that releases of pollutants into the waters of the Navajo Nation from point and non-point sources, introduction of pollutants by industrial users into publicly owned treatment works, and inappropriate management of sewage sludge are potential detriment to the health, welfare, and environment of the Navajo Nation and its citizen.

Furthermore, Navajo also requires at several places within Section 1311 that the water quality standards should be designed so as to protect the "cultural value" of the Nation's water. ${ }^{43}$ _Such a provision might be of particular value to tribes, as many have a special relationship with water that may include cultural and spiritual dimensions. ${ }^{44}$

Similar to the NN APPCA, the NN CWA provides an enforcement authority. The Nation may enforce the NN CWA through: 1) a compliance order, ${ }^{45}$ 2) administrative penalty; ${ }^{46} 3$ ) civil action. ${ }^{47}$ and 4 ) criminal enforcement. ${ }^{48}$ The NN CWA also permits for citizen suits if adequate notice (60 days) has been given.

\section{Navajo Nation Solid Waste Act ${ }^{49}$}

Navajo tribe has enacted Navajo Nation Solid Waste Act (NN SWA) ${ }^{50}$ that de-

$42 \quad$ Ibid. $\S 1303(\mathrm{~A})(1)$

$43 \quad$ Ibid. $\$ 1311(\mathrm{~A})$

44 Judith V. Royster. Climate Change and Tribal Water Rights: Removing Barriers to Adaptation Strategies, in Randall S. Abate \& Elizabeth Ann Kronk (eds). (2013). Climate Change and Indigenous Peoples: The Search for Legal Remedies. Massachusetts: Edward Elgar Publishing, pg.156

45 Ibid. $\S 1382(\mathrm{~B})$

$46 \quad$ Ibid. $\$ 1384$.

47 Ibid. $\$ 1383(\mathrm{~A})$

$48 \quad$ Ibid. $\S 1383(\mathrm{~B})$

49 Comprehensive Environmental Response, Compensation and Liability Act, Navajo Nation Code Ann. tit. 4, §§ 2101-2805 (2010)

50 Navajo Nation Code Ann. tit. 4, §§ 101-162 (2010) 
fines "solid waste" as "any garbage, refuse or sludge from a wastewater treatment plant, water supply treatment plant or air pollution control facility and other discarded material, including solid, liquid, semi-solid, or contained gaseous material resulting from residential, industrial, commercial, mining, and agricultural operations and from community activities." 51

In adopting the NN SWA, the Nation declared that the disposal of solid waste in or on the land without careful planning and management can present a danger to public health and the environment; that open dumping is particularly harmful to public health, potentially contaminates drinking water from underground and surface sources, and pollutes the air and the land; and that potentially recoverable material that could be recycled is needlessly buried each year, using scarce land resources, even though methods are available to separate usable materials from solid waste. ${ }^{52}$

The NN SWA provides that it shall be unlawful for any person to "[d]ispose of any solid waste in a manner that will harm the environment, endanger the public health, safety, and welfare or create a public annoyance." ${ }^{33}$ the NN SWA also provides various methods of enforcing its provisions through compliance orders, administrative penalties, civil enforcement, and criminal enforcement. ${ }^{54}$ Furthermore, the Act also authorizes citizen suits when certain conditions are met. ${ }^{55}$

\footnotetext{
Ibid. $\S 102(16)$

Ibid. at $\S 103(\mathrm{~A})$.

Ibid. $\$ 121(\mathrm{~A})(1)$

Ibid. § 152(A)(1)-(4).

Ibid. $\$ 155$.
}

\section{Right to Equitable Benefit Sharing and} Accountability for Breach

Navajo tribe has played an important role in the exploitation, control, and management of natural resources found on tribal lands, including exercising the power to issue leases or permits and to set rates for rent and royalties, and sharing other benefits accruing from the exploitation of their natural resources. ${ }^{56}$ Furthermore, it has a legal standing to maintain an action against the United States government for any breach of trust concerning tribal lands and resources whenever the tribes identify that they have been denied a fair and equitable benefit or that the federal government sustained unfavorable benefits or royalty rates on their behalf. ${ }^{57}$

In the United States v. Navajo Nation, ${ }^{58}$ the Secretary of the Interior approved a mining lease performed in 1964 between the Navajo tribe and the private company "Peabody Coal." The lease allowed the company to engage in coal mining on the Navajo reservation in exchange for royalty payments to the tribe. ${ }^{59}$ The maximum royalty rates were 37.5 cents per ton of coal, and a lease provision provided that the rates were "subject to reasonable adjustment by the Secretary of the Interior" after twenty years. ${ }^{60}$

Subsequently, in 1984, when the initial twenty-year period had passed, the tribe requested that the Secretary exercise his power to increase the royalty rate, because the 37.5

\footnotetext{
56 Leasing of Tribal Lands for Mineral Development, 25 C.F.R. pt. 211, subpt. C (Rents, Royalties, Cancellations and Appeals ( $\S 211.40-211.58))$

57 Eluyod, Op.Cit, pg 181

58 Navajo Nation v. United States (Navajo I), 46 Fed CI. 217, 225 (2000); Navajo Nation v. United States (Navajo II), 263 F.3d 1325 (Fed. Cir. 2001)

59 Navajo II. Ibid.

60 Ibid.
} 
cents per ton rate had become lower than the minimum royalty rate of $12.5 \%$ of gross proceeds set by the U.S. Congress. ${ }^{61}$ The Bureau of Indian Affairs (BIA) recommended adjusting the lease royalty rate to $20 \%$ of gross proceeds. However, the Secretary of Interior approved a royalty rate set at $12.5 \%$ of monthly gross proceeds. ${ }^{62}$ To respond this situation, Navajo Tribe brought an action against the United States seeking approximately $\$ 600$ million in damages on the basis that the Secretary's approval of a less favorable lease royalty amendment constituted a breach of trust by the U.S. government. ${ }^{63}$

\section{CONCLUSION}

It is unmistakable that Navajo Tribe has an ability to self-govern or self-administer their natural resources within their own territorial. Regarding law making process, this tribe can enact some acts to preserve control over their natural resources. Specifically, the Air Pollution Prevention and Control Act, the Clean Water Act, and the Solid Waste Act. Concerning law implementation and enforcement, Navajo Tribe has right to equitable benefit sharing in natural resources and accountability for breach. The application of rights for natural resources requires the U.S federal government to ensure fair administration or management of natural resources that complies with the interests and objectives of Navajo Tribe in the U.S. Eventually, this measure will mitigate an economic exploitation and ruthless extraction of natural resources in indigenous land.

\section{BIBLIOGRAPHY}

Abate, Randall S. \& Elizabeth Ann Kronk (eds). (2013). Climate Change and Indigenous Peoples: The Search for Legal Remedies. Massachusetts: Edward Elgar Publishing.

Aitken, Janice. (1997). "The Trust Doctrine in Federal Indian Law: A Look at Its Development and at How Its Analysis Under Social Contract Theory Might Expand Its Scope". Northern Illinois University Law Review, 18: 115.

Allen, Mark. "Native American Control of Tribal Natural Resource Development in the Context of the Federal Trust and Tribal Self-Determination". Boston College Environmental Affairs Law Review, 16: 857.

Anaya S. James. (2009). International Human Rights and Indigenous Peoples. Aspen Publ/Wolters Kluwer Law and Business.

Anaya, S. James Anaya \& Robert A. Williams, Jr. (2001). "The Protection of Indigenous Peoples' Rights over Lands and Natural Resources Under the Inter-American Human Rights System". Harvard Human Rights Journal, 14: 33.

Austin, Raymond D. (2009). Navajo Courts and Navajo Common Law: a Tradition of Tribal Self Governance. Minneapolis: University of Minnesota Press.

Eluyod, Jide James. (2012). "Collective Rights to Lands and Resources: Exploring the Comparative Natural Resource Revenue Allocation Model of Native American Tribes and Indig- 
enous African Tribes". Arizona Journal of International and Comparative Law, 29: 177.

Gover, Kevin. (2006). “An Indian Trust for the Twenty-First Century". Natural Resources Journal, 46: 340.

Lemont, Eric, (2002). "Developing Effective Process of American Indian Constitutional and Governmental Reform: Lessons from the Cherokee Nation of Oklahoma, Hualapai Nation, Navajo Nation, and Northern Cheyenne Tribe". American Indian Law Review, 26: 155.

Weber, Gloria Valencia. (1994). "Tribal Courts: Custom and Innovative Law". New Mexico Law Review, 24: 225.

\section{Website}

Ford Foundation, Expanding Community Rights Over Natural Resources, Initiative Overview, 2010, available at http:// www.fordfoundation.org/pdfs/issues/ community-rights-initiative-overview. pdf retrieved on 5 October 2015.

Navajo Tourism Dep't, The History of Cowboys and Indians, Discover Navajo, http://discovernavajo.com/Cowboys $\% 20 \& \% 20$ Indians-1.pdf. (last vi sited Sept. 16, 2014).

\section{International Treaties}

International Labour Organisation, Indigenous and Tribal Peoples Convention, 1989 (No. 169), June 27, 1989, 28
I.L.M. 1382

Declaration on the Rights of Indigenous Peoples, G.A. Res. 61/295, U.N. Doc. A/RES/61/295 (Sept. 13, 2007)

International Covenant on Civil and Political Rights, G.A. Res. 2200 (XXI) A, U.N.Doc.A/RES/220(XXI) (Dec. 16, 1966)

International Covenant on Economic, Social and Cultural Rights, G.A. Res. 2200 (XXI) A, U.N.Doc.A/RES/220(XXI) (Dec. 16, 1966)

\section{U.S Case Law}

Santa Clara Pueblo v. Martinez, 436 U.S. 49, 62-63 (1978)

Cherokee Nation v. Journeycake, 155 U.S. 196 (1894).

Navajo Nation v. United States (Navajo I), 46 Fed. CI. 217, 225 (2000)

Navajo Nation v. United States (Navajo II), 263 F.3d 1325 (Fed. Cir. 2001)

\section{Tribal Acts}

Navajo Nation Air Pollution Prevention and Control Act, Navajo Nation Code Ann. tit. 4, § 1101-1162 (2010).

Navajo Nation Water Code, tit. 22, ch. 7, $\S \S$ 101-1405 (1984).

Navajo Nation Code Ann. tit. 4, §§ 101-162 (2010)

Leasing of Tribal Lands for Mineral Development, 25 C.F.R. pt. 211, subpt. C (Rents, Royalties, Cancellations and Appeals (§§211.40-211.58) 